\title{
IMPLEMENTASI MANAJEMEN BERBASIS SEKOLAH SEBAGAI ALTERNATIF DESENTRALISASI PENDIDIKAN DI MAN 4 JAKARTA
}

\author{
Cut N. Ummu Athiyah \\ Pusdiklat Tenaga Teknis Pendidikan dan Keagamaan \\ Email: cutathiya@yahoo.com
}

\begin{abstract}
Abstrak
Artikel ini merupakan hasil riset terhadap penerapan Manajemen Berbasis Madrasah (MBM) sebagai alternatif desentralisasi pendidikan di MAN 4 Jakarta. Kajian ini menggunakan pendekatan kualitatif. Sampel penelitian ini menggunakan teknik purposive sampling dengan sampel terjangkau, terdiri atas unsur: kepala madrasah dan beberapa orang guru. Teknik pengumpulan data yang digunakan pada riset ini menggunakan observasi, studi dokumen dan wawancara. Teknik analisis data yang digunakan peneliti adalah analisis data model Miles and Huberman meliputi pengumpulan data, reduksi data, penyajian data, dan penarikan kesimpulan. Hasil penelitian penerapan MBM di MAN 4 Jakarta tahun 2017-2018 didapat kesimpulan bahwa pelaksanaanya telah berjalan dengan baik (sistematik, terencana, teratur, dan berkesinambungan).
\end{abstract}

Kata Kunci: Manajemen, Madrasah, Otonomi

\begin{abstract}
This article is the result of research on the application of School Based Management as an alternative to decentralization of education in MAN 4 Jakarta. This study uses a qualitative approach. The research sample used a purposive sampling technique with affordable samples, consisting of elements: the madrasa head and his deputy. The data collection technique used in this research uses observation, document study and interviews. The data analysis technique used by researchers is the data analysis of the Miles and Huberman model including data collection, data reduction, data presentation, and conclusion drawing. The results of the research on the application of MBM in MAN 4 Jakarta in 2017-2018 concluded that the implementation had been going well (systematic, planned, organized, and continuous).
\end{abstract}

Keywords: Management,Madrasah,Autonomy 
PENDAHULUAN

S elama dua dekade terakhir ini, salah satu isu yang paling banyak diperdebatkan dalam dunia pendidikan terakhir ini adalah bagaimana menemukan keseimbangan antara sentralisasi dan desentralisasi pendidikan Caldwell, B. J. (2008:235252). Dalam konteks pengelolaan sekolah negeri, desentralisasi kekuasaan dan kewenangan terjadi di tingkat satuan pendidikan bertujuan untuk memberdayakan para pemangku kepentingan sekolah dalam pengambilan keputusan sebagaimana dahulu menjadi kewenangan pemerintah pusat (Smith S. C. \& P. K. Piele, 2006-223-244).

Melalui penerapan MBS diyakini bahwa kepala sekolah, guru, staf administrasi sekolah, juga orang tua dan masyarakat setempat merupakan penentu strategi yang paling sesuai dengan kebutuhan peserta didik atau anak-anak mereka. Oleh karena itu MBS tidak hanya diterima di negara maju seperti Amerika,Australia, Selandia Baru, Hongkong tapi juga di negara-negara berkembang seperti Thailand dan Indonesia. Temuan penelitian dalam dua dekade terakhir menunjukkan bahwa penerapan Manajemen Berbasis Masyarakat pada sekolah mampu memberdayakan dan meningkatkan partisipasi serta kemitraan orangtua dan masyarakat. (Bandur, 2012,316-328); Penerapan MBS diyakini membantu sekolah untuk meningkatkan kualitas pendidikan, memberikan pengajaran dan pembelajaran yang lebih sehat lingkungan, dan meningkatkan hasil siswa.
Ahli lain, Bjork (2003:193) mencatat sejalan dengan pelaksanaan otonomi daerah di Indonesia, ide penerapan MBS menjadi paradigma baru dalam pengoperasian sekolah. Telah menjadi sebuah fenomena sejak lama bahwa sekolah menjadi perpanjangan tangan birokrasi pemerintah pusat untuk menyelenggarakan urusan politik pendidikan. Memasuki abad 21, Indonesia menjadi salah satu dari negara yang memiliki kekuatan sentralisasi tertinggi di dunia. Apabila dilihat dari konteks dunia pendidikan dapat diartikan kepala sekolah dan guru serta komite/orangtua belum memiliki banyak kelonggaran mengelola dan mengambil keputusan secara mandiri. Kebijakan penyelenggaran pendidikan lebih banyak diputuskan di tingkat pemerintah pusat atau pada instansi vertikal daripada di tingkat satuan pendidikan. Sekolah hanya menerima apa adanya. Sebagai contoh, muatan kurikulum satuan pendidikan menjadi urusan pusat, sementara stakeholder di satuan pendidikan (guru, kepala sekolah, dll) hanya melaksanakan sesuai dengan petunjuk pelaksanaan dan petunjuk teknisnya.

Mekanisme anggaran negara untuk pendidikan mengalir dari pusat ke daerah melalui jalur birokrasi dan memiliki banyak simpul. Masing-masing lini menginginkan bagian. Implikasinya, pada tingkat satuan pendidikan sebagai satuan paling operasional anggaran yang diterima menyusut. Kekhawatiran sebagian besar anggaran dialokasikan untuk hal-hal yang tidak jelas arahnya.

Penerapan MBS/M sebenarnya bukan sebuah upaya yang mudah karena 
berimplikasi berbagai isu kebijakan dan melibatkan banyak lini kewenangan dalam pengambilan keputusan serta tanggung jawab dan akuntabilitas atas konsekuensi keputusan yang diambil. Diperlukan kesungguhan dan kesadaran semua pihak yang terlibat tentang apa itu MBS, apa manfaatnya, apa saja masalahmasalah dalam penerapannya, dan yang paling penting adalah apa dan bagaimana pengaruhnya terhadap keberlangsungan manajemen sekolah.

Menurut Rivai (2009: 139-143), penerapan konsep MBS setidaknya mempunyai tiga tujuan: 1) Mengembangkan kemampuan kepala sekolah bersama guru dan unsur komite sekolah dalam aspek Manajemen Berbasis Sekolah (MBS) untuk meningkatkan mutu sekolah, (2). Mengembangkan kemampuan kepala sekolah bersama guru dan unsur komite sekolah dalam pelaksanaan pembelajaran yang aktif dan menyenangkan, baik di sekolah maupun di lingkungan masyarakat setempat, 3) Mengembangkan peran serta masyarakat yang lebih aktif dalam masalah umum persekolahan dan unsur komite sekolah dalam membantu peningkatan mutu sekolah.

Dalam reserch, ini peneliti akan melihat manajemen MAN 4 Jakarta berdasarkan konsep MBS, dimana MBS dijadikan sebagai ukuran dalam menilai keberlangsungan manajemen dalam mengelolah madrasah tersebut. Setidaknya ada tujuh masalah yang terindentifikasi sebagai bagian dari komponen MBS, yaitu: 1) Manajemen kurikulum dan program pengajaran, 2) Manajemen tenaga kependidikan, 3) Manajemen kesiswaan, 4) Manajemen keuangan dan pembiayaan, 5) Manajemen sarana dan prasarana pendidikan, dan 6) Manajemen hubungan sekolah dan masyarakat; 7) Manajemen layanan khusus. (Suharsimi,2008:4). penelitian ini difokuskan pada tiga aspek yaitu: 1) Manajemen kurikulum pembelajaran, 2) manajemen tenaga pendidik, dan 3) Manajemen peserta didik.

\section{METODOLOGI}

Jenis penelitian ini adalah penelitian deskriptif evaluatif. Penelitian deskriptif memberikan gambaran secara sistematis, faktual dan akurat sebuah fenomena atau hubungan antar fenomena yang diselidiki. (Suprayogo, Tobroni, 2001: 136-137). Dalam penelitian ini semua informasi yang didapat dari observasi, wawancara, dan dokumen dideskripsikan dalam bentuk narasi tulisan sebagai bentuk temuan di lapangan. Penelitian ini menggunakan MBS sebagai barometer dalam menilai manajemen di Madrasah Aliyah Negeri 4 Jakarta Selatan.

Subyek penelitian menggunakan teknik purposive sampling, yaitu cara penentuan informan yang ditetapkan secara sengaja atas dasar kriteria atau pertimbangan tertentu. Dalam penelitian ini, pemilihan informan didasarkan kriteria dengan urutan sebagai berikut:

a. Kepala Madrasah Aliyah Negeri 4 Jakarta Selatan. Bapak Ismail Nur, Lc., M.Ag.

b. Para Wakil Kepala Sekolah sejumlah 6 orang (Bidang Kurikulum, Bidang Kesiswaan, Bidang Sarana dan Prasana, Bidang Humas, Bidang 
Pengembangan Mutu dan Wakil Asrama).

\section{Waktu dan Tempat Penelitian}

Penelitian kecil ini dilakukan pada bulan September 2017 s.d. April 2018 bertepatan dengan kegiatan obeservasi lapangan Diklat Teknis Substantif Penguatan Kepala Madrasah Pusdiklat Tenaga Teknis Pendidikan dan Keagamaan yang bertempat di MAN 4 Jakarta Selatan, Jl. Ciputat Raya RT. 5/RW. 8, Pondok Pinang, Kebayoran Lama, Pondok Pinang, Kebayoran Lama, Jakarta Selatan, Jakarta 12310.

\section{KAJIAN TEORITIK}

\section{Manajemen Berbasis Sekolah/ Madrasah (MBS/M)}

Undang- Undang Nomor 20 tahun 2003 tentang Sistem Pendidikan Nasional secara jelas menyatakan bahwa pendidikan yang bermutu dapat mengembangkan dirinya secara aktif supaya memiliki pengendalian diri, kecerdasan keterampilan dalam masyarakat, kekuatan spritual keagamaan, keperibadian serta akhlak mulia. Sehingga pendidikan menjadi proses yang bermakna dalam membangun masyarakat.

Dalam konteks outcome, pendidikan nasional harus mampu menghasilkan lulusan yang memiliki kemampuan intlektual dan akhlak mulia secara seimbang. Dalam bahasa visi 2025 Kemendiknas, pendidikan di selenggarakan untuk menghasilkan " insan Indonesia cerdas dan kompetitif (insan kamil atau insan sempurna); yaitu Indonesia yang cerdas spritual, cerdas emosional, cerdas sosial, cerdas intlektual dan cerdas kinestesis. Undang-undang No. 20 pasal 51 , ayat (1) juga secara tegas mengamanatkan pengelolaan satuan pendidikan termasuk madrasah dengan prinsip MBS/M sebagaimana berikut: "Pengelolaan satuan pendidikan anak usia dini, pendidikan dasar, dan pendidikan menengah dilaksanakan berdasarkan standar pelayanan minimal dengan prinsip manajemen berbasis sekolah/madrasah."

Dalam penjelasan pasal 51 , ayat (1) "bentuk otonomi manajemen pendidikan pada satuan pendidikan, yang dalam hal ini kepala sekolah/madrasah dan guru dibantu oleh komite sekolah/madrasah dalam mengelola kegiatan pendidikan".

Amanat pelaksanaan MBS/M juga terdapat pada Peraturan Pemerintah Nomor 17 tahun 2007 pasal 49; “Pengelolaan satuan pendidikan pada jenjang pendidikan dasar dan menengah menerapkan manajemen berbasis sekolah".

Admodiwirio menyatakan bahwa untuk meningkatkan mutu sekolah dapat dilakukan melalui otonom sekolah. Oleh karna itu penerapan manajemen berbasis sekolah perlu diberikan kepercayaaan untuk mengatur dan mengurus dirinya sendiri sesuai dengan kondisi lingkungan dan kebutuhan pelanggan guna mencapai tujuan - tujuan pendidikan. Admodiwirio (2000:5-6). Pemikiran tersebut mendorong munculnya pendekatan baru, yaitu dengan pengelolaan kualitas pendidikan berbasis sekolah.

Priscilla Wohltetter dan Albert Mohram menjelaskan bahwa pada hakikatnya Manajemen Berbasis Sekolah 
berpijak pada Self Determination Theory. Teori ini menyatakan bahwa apabila seseorang atau sekelompok orang memiliki kepuasan untuk mengambil keputusan sendiri, maka orang tersebut akan memiliki tanggung jawab yang besar untuk melakukan apa yang telah diputuskan. (2004:204-205)

Menurut Levacic dalam Bafadal terdapat tiga karakteristik manajemen berbasis sekolah/madrasah (MBS/M) yang harus dikedepankan diantaranya adalah: pertama, kekuasaan dan tanggung jawab dalam pengambilan keputusan yang berhubungan dengan peningkatan mutu pendidikan yang didesentralisasikan pada stakeholder sekolah. Kedua, domain manajemen peningkatan mutu pendidikan yaang mencakup seluruh aspek peningkatan mutu pendidikan mencakup kurikulum, kepegawaian, keuangan, sarana prasarana dan penerimaan siswa baru. Ketiga, walaupun keseluruhan domain sekolah, namun diregulasikan yang mengatur fungsi kontrol terhadap keseluruhan pelaksanaan kewenangan dan tanggung jawab pemerintah. Bafadal(2006:82)

Menurut Miarso (2004:277-278) Manajemen Berbasis Sekolah (MBS) adalah pelimpahan wewenang pada lapis sekolah untuk mengambil keputusan mengenai alokasi dan pemanfaatan sumber-sumber berdasarkan aturan akuntabilitas yang berkaitan dengan sumber tersebut. Mutu dan kualitas outcome sudah tentu harus dipertahankan agar lembaga tersebut memiliki daya saing yang kuat dengan lembaga pendidikan yang lainnya.
Mulyasa (2009 : 11) menjelaskan bahwa MBS merupakan bentuk alternatif sekolah dalam program desentralisasi bidang pendidikan, yang ditandai oleh otonomi luas di tingkat luas, partisipasi masyarakat dan dalam kerangka kebijakan pendidikan nasional. Otonomi ini diberikan agar sekolah dapat leluasa mengelola sumber daya mengalokasikannya sesuai prioritas kebutuhan serta tanggap terhadap kebutuhan masyarakat setempat. Partisipasi masyarakat dituntut agar lebih memahami pendidikan, membantu mengontrol pengelolaan pendidikan. Dalam hal ini sekolah dituntut memiliki tanggung jawab yang tinggi, baik kepada orang tua, masyarakat maupun pemerintah.

Jelas bahwa desentralisasi melalui Sekolah Berbasis Sekolah Manajemen menjadi sangat penting untuk meningkatkan kualitas pendidikan di Indonesia baik dalam proses pembelajaran, budaya sekolah, dan prestasi belajar siswa.

\section{Karakteristik Ideal Manajemen Berbasis Sekolah/Madrasah}

Seperti digambarkan sebelumnya, paradigma manajemen berbasis sekolah/madrasah yang ditawarkan pemerintah sesungguhnya merupakan salah satu bentuk operasional desentralisasi pendidikan dalam kontek otonomi daerah. Tujuannya adalah agar diperoleh dan diciptakan peningkatan efisiensi dan efektifitas kinerja sekolah/madrasah, dengan penyediaan layanan pendidikan yang komprehensif dan tangggap terhadap kebutuhan masyarakat. Hal ini juga didasarkan pada suatu kenyataan bahwa peserta di sekolah 
pada setiap daerah memiliki kemampuan dan keadaan latar belakan ekonomi, sosial budaya, yang berbeda-beda yang harus disalurkan dan dikembangkan dengan bijaksana. Dalam hal ini sekolah/madrasah dalam penyelenggaraan pendidikan pertimbangan eksistensi peserta didik yang sangat heterogen tersebut menjadi amat urgen.

Berkaitan dengan karakteristik sekolah/madrasah E. Mulyasa telah mengidentifikasi beberapa karakteristik Manajemen Berbasis Sekolah/Madrasah menurut Mulyasa (2003:24) sebagai berikut:

1. Pemberian Otonomi Luas kepada Madrasah

Manajemen

Berbasis

Sekolah/Madrasah memberikan otonomi luas kepada madrasah, disertai seperangkat tanggung jawab untuk mengelola sumber daya dan pengembangan strategi sesuai dengan kondisi setempat. Madrasah juga diberi kewenangan dan kekuasaan yang luas untuk mengembangkan programprogram kurikulum dan pembelajaran sesuai dengan kondisi dan kebutuhan peserta didik serta tuntutan masyarakat. Selain itu, madrasah juga diberikan kewenangan untuk menggali dan mengelola sumber dana sesuai dengan prioritas kebutuhan. Melalui otonomi yang luas, madrasah dapat meningkatkan kinerja tenaga pendidikan dengan menawarkan partisipasi aktif mereka dalam pengambilan keputusan dan bertanggung jawab bersama dalam pelaksanaan keputusan yang diambil secara proporsional dan profesional.
2. Tingginya Partisipasi Masyarakat.

Dalam MBM, pelaksanaan program-program madrasah didukung oleh tingginya partisipasi masyarakat dan orang tua peserta didik. Orang tua peserta didik dan masyarakat tidak hanya mendukung sekolah/madrasah melalui bantuan keuangan, tetapi melalui komite madrasah dan dewan pendidikan merumuskan serta mengembangkan program-program yang dapat meningkatkan kualitas madrasah. Madrasah dan orang tua menjalin kerjasama untuk memberikan bantuan dan pemikiran serta menjadi narasumber pada berbagai kegiatan peningkatan kualitas pembelajaran di sekolah/madrasah.

3. Kepemimpinan yang Demokratis dan Profesional.

Dalam MBM, pelaksanaan program-program madrasah di dukung oleh adanya kepemimpinan madrasah yang demokratis dan profesional. Kepala madrasah dan guru-guru sebagai aktor utama program madrasah merupakan figur yang memiliki kemampuan dan integritas profesaional. Kepala madrasah merupakan manajer pendidikan profesional yang direkrut komite sekolah/madrasah untuk mengelola segala kegiatan madrasah berdasarkan kebijakan yang ditetapkan. Guru-guru yang direkrut oleh madrasah adalah pendidik profesional dalam bidangnya masing- masing, sehingga mereka bekerja berdasarkan pola kinerja profesional yang di sepakati bersama untuk memberi kemudahan dan mendukung keberhasilan pembelajaran peserta didik. Dalam proses pengambilan keputusan, kepala madrasah 
mengimplementasikan proses Bottom up secara demokratis, sehingga semua pihak memiliki tanggung jawab terhadap keputusan yang diambil beserta pelaksanaannya.

4. Teamwork yang Kompak dan Transparan.

Dalam MBS/MBM, keberhasilan program-program sekolah/madrasah didukung oleh kinerja tim yang kompak dan transparan dari berbagai pihak yang terlibat dalam pendidikan di madrasah. Dalam dewan pendidikan dan komite sekolah/madrasah misalnya, pihak-pihak yang terlibat bekerjasama secara harmonis sesuai dengan posisinya masing-masing untuk mewujudkan suatu sekolah/madrasah yang dapat dibanggakan oleh semua pihak. Mereka tidak saling menunjukkan kuasa atau paling berjasa, tetapi masing-masing berkontribusi terhadap upaya peningkatan mutu dan kinerja madrasah secara kaffah. Dalam pelaksanaan program misalnya, pihak-pihak terkait bekerjasama secara profesional untuk mencapai tujuan-tujuan atau target yang disepakati bersama. Dengan demikian keberhasilan MBS/MBM merupakan hasil sinergi dari kolaborasi team yang kompak dan transparan. Dalam konsep MBS/MBM yang utuh kekuasaan yang dimiliki sekolah/madrasah, diantaranya adalah pengembalian keputusan tentang manajemen kurikulum dan pembelajaran, rekrutmen dan manajemen tenaga kependidikan, serta manajemen keuangan sekolah/madrasah.

Dalam rangka menjawab harapan sekolah/madrasah meningkatkan mutu pendidikan maka dalam konteks MBS/MBM haruslah mengikuti empat prinsip MBS/MBM, yaitu: (1) Prinsip equifinalitas (equifinality) yang di dasarkan pada teori manajemen modern yang berasumsi bahwa terdapat perbedaan cara untuk mencapai tujuan; (2) prinsip desentralisasi (decentralization); (3) prinsip sistem pengelolaan mandiri (self managing system); (4) prinsip inisiatif manusia (human initiative). Susan Albers Moharman (1994:48-58)

Pendapat sebaliknya dinyatakan oleh Brian J. Cadwell dan Jim M. Spink, J.C Anderson (1998:66) yang menyatakan bahwa untuk meningkatkan mutu pendidikan dengan pendekatan Manajemen Berbasis Sekolah (MBS) tidak memiliki pengaruh yang signifikan.

Permasalahan lain yang terkait dengan penerapan Manajemen Berbasis Sekolah (MBS) adalah banyaknya orang tua siswa dan masyarakat khususnya di pedesaan yang tidak mau terlibat dalam komite sekolah. Permasalahanya bukan pada mutu yang rendah tetapi lebih karna kepada budaya yang hanya menyerahkan sepenuhnya urusan pendidikan kepada sekolah. Dengan MBS seakan-akan pemerintah telah memberikan otonomi kepada sekolah, padahal sekolah dan masyarakat belum siap untuk menerima semua itu. (William Whitaaker, 2003:86).

Dharma (2003) menyatakan bahwa hambatan manajemen berbasis sekolah (MBS) untuk diterapkan adalah: (1) sulitnya menerapkan model baru, (2) pihak yang berpastisipasi masih terpengaruh oleh konsep lama, (3) penerapan MBS tidak komprehensif, (4) MBS tidak terkonsntrasi kepada prestasi 
pendidikan, (5) MBS terkonsentrasi di luar pembelajaran.

Penelitian lain yang dilakukan oleh Mustiningsih (2015:501-503), hasil penelitiannya menunjukkan bahwa masalah implementasi manajemen berbasis sekolah (MBS) di Indonesia secara berturut-turut yaitu: manajemen pembiayaan $(100 \%)$, manajemen pendidik dan tenaga kependidikan $(88 \%)$, manajemen budaya dan lingkungan sekolah (75\%), manajemen peserta didik $(73 \%)$, manajemen sarana dan prasarana $((71 \%)$, manajemen humas $(60 \%)$, dan manajemen pembelajaran (40\%). Masalah yang masih ada adalah dalam implementasi komponen-komponen MBS tersebut karna berbagai faktor, dan diantara faktor-faktor itu adalah lemahnya peran dan kepemimpinan kepala sekolah dan minimnya kerjasama sekolah dengan masyarakat. Jenni

menyatakan hasil penelitiannya tentang implementasi MBS, terdapat sejumlah masalah dalam implementasi MBS, yaitu pertama, ketidakmampuan organisasi sekolah untuk mengimplementasikan MBS sesuai dengan langkah-langkah MBS karna kurangnya kemampuan dan pengalaman sekolah untuk mengadopsi perubahan. Sumber daya di Indonesia sulit menerima perubahan, inginnya sudah mapan dengan yang lama, dan aman dengan yang lama. Kedua, inovasi MBS dibangun tanpa ada perencanaan yang jelas dan jadwal yang pasti. Ketiga, kurang aplikatifnya desain model MBS. Hal ini menyebabkan kurang jelasnya dalam implementasi di lapangan. Keempat, jalur birokrasi/komunikasi tidak memberikan pemahaman yang jelas tentang MBS. Di Indonesia wilayahnya terlalu luas dan terlalu beragam sehingga jalur birokrasinya terlalu lama dan panjang. Kelima, kurang banyaknya latihan/penataran dan hasil-hasil latihan/penataran tidak diterapkan di lapangan.

Senyampang dengan itu dalam kesimpulan penelitiannya, Bandur (2012) menyatakan bahwa desentralisasi melalui MBS menjadi sangat penting untuk meningkatkan kualitas pendidikan di Indonesia khususnya berkenaan dengan proses pembelajaran, ekosistem dan budaya sekolah, dan yang paling penting prestasi belajar siswa. Di tingkat kebijakan, kekuatan pengambilan keputusan seharusnya diserahkan pada satuan pendidikan sepenuhnya tanpa bisa ditawar-tawar lagi, termasuk perumusan visi sekolah, misi dan tujuan, anggaran, renovasi bangunan, pembuatan bangunan baru, pemeliharaan, kebijakan disiplin, pengembangan kurikulum, dan pemilihan guru, kepala sekolah, administrasi staf dan buku teks. Dalam prakteknya, efektifitas implementasi MBS memiliki tantangan yang tinggi dan semua akhirnya tergantung kesiapan dan kemauan dari stakeholder.sekolah itu sendiri.

Dalam upaya menerapkan Manajemen Berbasis Sekolah/Madrasah (MBS/M) kepala madrasah memiliki peran yang berbeda melebihi perannya dalam model non-MBS/M. Menurut Mulyono (2008:164) perbedaan tersebut menuntut kepala sekolah/madrasah untuk memiliki multi skill. Mulyono menjelaskan bahwa kepala sekolah merupakan ruh yang menjadi pusat 
sumber gerak organisasi pendidikan untuk mencapai tujuan jauh dijelaskan bahwa kepala sekolah adalah tokoh sentral pendidikan dalam menentukan arah kebijakan mutu pendidikan.

Berdasarkan pembahasan di atas dapat disimpulkan bahwa karakteristik manajemen berbasis sekolah/manajemen berbasis madrasah adalah segala hal yang menjadi kebutuhan dalam keadaan sekolah/madrasah yang kemudian keadaan tersebut diberi kewenangan melakukan pengelolaan sekolah/ madrasah sendiri secara otonomi atau berdiri sendiri dengan segala kemungkinan yang dihadapinya serta mampu menjawab tantangan yang dihadapi dengan keluasan peran dan tanggungjawab yang dilimpahkan.

\section{Analisis Kritis Implementasi MBM Di MAN 4 Jakarta}

Madrasah Aliyah Negeri (MAN) 4 Jakarta Selatan adalah Lembaga Pendidikan tingkat SLTA yang berwawasan global dengan ciri khas Keislaman.

MAN 4 Jakarta Selatan memiliki visi Terwujudnya Pendidikan Islami Unggul dalam Prestasi.

Sementara, misi MAN 4 Jakarta Selatan adalah sebagai berikut :

a. Mewujudkan sistem pembinaan keagamaan yang islami.

b. Mewujudkan sistem akademik dan non akademik yang sistematis, profesional dan berkelanjutan yang berorientasi pada tercapainya prestasi nasional.

c. Menyelenggarakan pembinaan kompetensi guru dan profesionalitas pegawai yang berintegritas. d. Mewujudkan sistem pembinaan kecakapan global yang sistematis, mendalam, aplikatif dan berkelanjutan.

e. Mewujudkan sarana dan prasarana madrasah yang lengkap, berkualitas dan terawat.

f. Menyediakan tata kelola madrasah yang handal dan menjamin terselenggaranya layanan prima.

g. Mewujudkan sistem pembinaan asrama yang sistematis, kreatif, efektif, inovatif, menyenangkan, dan Islami.

h. Mewujudkan monitoring dan evaluasi sistem administasi manajemen madrasah.

Lindquist dan Mauriel (1989:403416) dalam penelitiannya menyatakan bahwa sekolah yang efektif adalah sekolah yang melakukan perubahan di sekolah dengan school based management, yang menekankan kepada pengembangan perencanaan sekolah, peningkatan kualitas sekolah, implementasi kurikulum/program baru dan aplikasi teknologi informasi dalam pendidikan. Hasil wawancara dan pencermatan dokumen di MAN 4 Jakarta, menunjukkan bahwa penyusunan Rencana Kegiatan dan Anggaran Madrasah (RKA-M) pada tahun 2018 telah disusun melalui mekanisme yang baik. Hasil Evaluasi Diri Madrasah yang merekomendasikan beberapa program urgen telah ditindaklanjuti dalam bentuk kegiatan dan alokasi anggaran.

\section{Analisis Manajemen Kurikulum Pembelajaran}

Dalam konteks perencanaan kurikulum MTs Negeri 20 Jakarta setiap 
tahunnnya telah melakukan berbagai upaya agar kurikulum dan muatannya benar-benar sesuai dengan apa yang diharapkan. Kesesuaian kurikulum dan muatannya diharapkan dapat memberikan sumbangsih positif dalam mencapai visi dan misi yang sudah dicanangkan. Sementara pada pelaksanaan kurikulum telah berjalan sesuai dengan regulasi terbaru yaitu Kurikulum Tingkat Satuan Pendidikan (KTSP) yang mengacu kepada kurikulum 2013. Hal tersebut peneliti dapatkan melalui hasil pengecekan dokumen 1,2, dan 3 KTSP MAN 4 Jakarta yang telah disusun. Pada aspek pengelolaan proses pembelajaran juga sepenuhnya diserahkan pada guru yang mengampu mata pelajaran dan telah berjalan sesuai dengan amanat kurikulum 2013 yaitu pembelajaran yang berpusat pada peserta didik serta menggunakan pendekatan saintifik. Namun masih ada persoalan dalam menerjemahkan kurikulum ke dalam proses pembelajaran pada sebagian guru, terutama pada aspek penilaian pembelajaran. Penilaian pembelajaran masih menitikberatkan pada assessment as learning belum assessment for learning sebagaimana tuntutan kurikulum 2013.

Kurikulum yang terencana, dan terlaksana tentu tidak akan terus berjalan sesuai dengan apa yang diharapkan, dalam perjalannya tentu banyak menghadapi berbagai kendala, baik dari pihak manajemen, guru, dan juga kondisi dan keadaan di lapangan.

Oleh karena itu MAN 4 Jakarta melakukan supervisi kurikulum yang mana dalam pelaksanaannya dilakukan oleh pihak pemerintah seperti pengawas sekolah pada madrasah yang berasal dari Kantor Wilayah Kementerian Agama wilayah Jakarta Selatan, dan juga kepala MAN 4 Jakarta. Adapun sasaran supervisi meliputi para guru sebagai eksekutor pelaksana kurikulum di kelas dan juga perangkat pembelajaran yang dimiliki oleh para guru, seperti Silabus, RPP dan lainnya. Dari hasil wawancara dan dokumen KTSP menunjukkan bahwa pengelolaan kurikulum telah berjalan dengan baik. Guru-guru memiliki kesadaran dalam menyusun RPP nya secara mandiri difasilitasi oleh manajemen MAN 4 Jakarta.

\section{Analisis manajemen tenaga pendidik}

Jumlah pendidik MAN 4 Jakarta Selatan mencapai 99 orang dan Tenaga Kependidikan berjumlah 53 orang. Tenaga pendidik yang handal dan kompeten akan bisa menghasilkan kinerja yang baik dan pada ahirnya akan menghasilkan output yang baik pula. Oleh karena itu dalam rangka mencapai dan mandapatkan tenaga pendidik yang baik dan professional kepala sekolah MAN 4 Jakarta melakukan langkah-langkah sebagai berikut:

Perekrutan tenaga pendidik baru di MAN 4 Jakarta dilakukan setelah kepala sekolah melakukan analisis kebutuhan dan ketersediaan posisi baru yang dianggap penting dan harus diadakan. Salah seorang wakil Kepala sekolah menuturkan bahwa dalam perekrutan tenaga pendidik baru ada dua cara yang biasa ditempuh oleh pihak sekolah. Pertama, pihak sekolah melalui rapat dewan guru melayangkan surat permintaan kepada kantor Wilayah 
Kementerian Agama Jakarta Selatan dengan persayaratan dan jumlah yang dibutuhkan. Kedua, kepala sekolah melalui rapat dewan guru merekrut tenaga pendidik baru non PNS sehingga tenaga pendidik tersebut bisa menempatai posisi yang kosong.

Penerimaan tenaga pendidik baru di MAN 4 Jakarta harus memiliki berbagai macam persyaratan yang ditentukan baik persyaratan umum maupun khusus. MAN 4 Jakarta memberikan kesempatan pada guru untuk melakukan pengembangan profesinya. Dari hasil Evaluasi Diri Madrasah ditemukan beberpa hal berikut: MAN 4 Jakarta telah menyusun progaram pendayagunaan pendidik dan tenaga kependidikan dengan memperhatikan standar PTK, Sekolah memiliki Program pembagian tugas guru, Sekolah menerapkan program pendayagunaan PTK secara profesional, adil, dan terbuka, Sekolah mendukung upaya: promosi PTK, Pengembangan PTK, Penempatan PTK sesuai kebutuhan, dan mutasi tenaga kependidikan, dan sekolah kami mendayagunakan guru untuk melaksankan tugas dan tanggung jawabnya sebagai agen pembelajaran yang memotivasi, memfasilitasi, mendidik, membimbing, dan melatih peserta didik.

Sekolah perlu melakukan pemetaan dan redistribusi Ratio jumlah guru:siswa = 1:17 (melebihi standar), Sekolah perlu perlu melakukan pemetaan dan redistribusi Ratio jumlah guru : beban kerja $\mathrm{PBM}=1: 15$ (agar memenuhi standar minimal 24 jam, atau dengan kata lain tidak over quota guru, Sekolah perlu Jumlah guru menurut data kualifikasi pendidikan secara merata, (terdapat guru yang over quota pada mata pelajaran IPS, Matematika, IPA, Seni Budaya, Bahasa Inggris, Bahasa Indonesia, PKn.), Sekolah perlu melakukan usul pemenuhan Guru mata pelajaran yang kurang meliputi Bahasa Sunda, Mulok PLH, Mulok Ekonomi Syariah, sekolah perlu melakukan pembinaan dan pemetaan serta redistribusi guru yang miss-macth.

Berdasarkan hal-hal tersebut diatas dapat disimpulkan manajemen tenaga pendidik/guru di MAN 4 telah berjalan cukup baik. Untuk beberapa persoalan yang bersifat eksternal seperti adanya intervensi kebijakan dalam penempatan guru dari Kementerian Agama memang diperlukan dikarenakan sebagian besar guru MAN 4 berstatus PNS.

\section{Manajemen Peserta Didik}

Peserta didik berjumlah 1049 orang, laki-laki berjumlah 387 dan perempuan berjumlah 662 . Kelas $X$ berjumlah 323 orang ( $\mathrm{Lk}=129, \mathrm{Pr}=$ 194), Kelas XI berjumlah 342 orang (Lk = 127, $\mathrm{Pr}=215)$ dan Kelas XII berjumlah $384(\mathrm{Lk}=131, \operatorname{Pr}=253)$.

Perencanaan penerimaan peserta didik baru di MAN 4 Jakarta sesuai dengan informasi yang didapat dari wakil kepala sekolah bidang kesiswaan disarankan pada faktor:

Kebijakan pemerintah (Kanwil Kemenag), situasi dan kondisi ruangan yang tersedia, dan anggaran yang ada.

Madrasah MAN telah melakukan manajemen mutu peserta didik agar memiliki karakter melalui pembiasaan: TTD, Zikir, dan Taklim Mutaalim kepada Guru Karyawan serta Siswa tanpa meninggalkan ciri kemadrasahan berakhlaqul karimah. Dan selalu berlatih, 
berinteraksi dengan pendidikan terkait dan beradaptasi dengan teknologi selama dalam koridor pendidikan dan bukan untuk yang negatif. Dari dokumen EDM ditemukan beberapa hal penting terkait manajemen peserta didik: MAN 4 Jakarta masih perlu mengupayakan untuk mengoptimalkan pembelajaran, sehingga makin dikurangi adanya siswa yang mencapai KKM melalui remedial pembelajaran lebih dari 2 kali, sekolah perlu mengupayakan angka tidak naik kelas $($ TNK) $=0 \%$, sesuai kriteria kenaikan kelas yang ditetapkan, sekolah perlu mengupayakan capaian Nilai ratarata UN di atas 8,0, sekolah melengkapi/menyempurnakan

Keseluruhan bukti fisik prestasi siswa yang belum dibuat dan belum terdokumentasikan dengan baik, terpublikasikan dengan baik untuk kepentingan pencitraan sekolah, sekolah juga perlu terus mendorong kemandirian peserta didik dalam mengembangkan keterampilan berpikir logis, kritis, dan analititis serta mengembangkan kreatifitas mereka, serta mengarahkan peserta didik mampu menjadi pembelajar yang mandiri.

\section{Langkah Pemecahan Masalah Manajemen Berbasis Madrasah Di MAN 4 Jakarta}

Pada dasarnya, mengubah pendekatan manajemen berbasis pusat menjadi manajemen berbasis sekolah bukanlah merupakan one-shot and quickfix, akan tetapi merupakan proses yang berlangsung secara terus menerus dan melibatkan semua unsur yang bertanggung jawab dalam penyelenggaraan pendidikan persekolahan. Oleh karena itu, strategi utama yang perlu ditempuh dalam melaksanakan manajemen berbasis sekolah adalah sebagai berikut (Slamet PH, 2000; Direktorat Dikmenum, 2000) Mensosialisasikan konsep manajemen berbasis sekolah ke seluruh warga sekolah, yaitu guru, siswa, wakilwakil kepala sekolah, konselor, karyawan dan unsur-unsur terkait lainnya (orang tua murid, pengawas, wakil kanwil kementerian Agama, dsb), melalui seminar, diskusi, forum ilmiah, dan media massa. hendaknya dalam sosialisasi ini juga dibaca dan dipahami sistem, budaya, dan sumber daya sekolah yang ada secermat-cermatnya dan direfleksikan kecocokannya dengan sistem, budaya, dan sumber daya yang dibutuhkan untuk penyelenggaraan manajemen berbasis sekolah.

1. MAN 4 Jakarta melakukan analisis situasi sekolah dan luar sekolah yang hasilnya berupa tantangan nyata yang harus dihadapi oleh sekolah dalam rangka mengubah manajemen berbasis pusat menjadi manajemen berbasis sekolah. Tantangan adalah selisih (ketidaksesuaian) antara keadaan sekarang (manajemen berbasis pusat) dan keadaan yang diharapkan (manajemen berbasis sekolah). Karena itu, besar kecilnya ketidaksesuaian antara keadaan sekarang (kenyataan) dan keadaan yang diharapkan (idealnya) memberitahukan besar kecilnya tantangan (loncatan).

2. Merumuskan tujuan situasional yang akan dicapai dari pelaksanaan manajemen berbasis sekolah berdasarkan tantangan nyata yang 
dihadapi (butir 2). Segera setelah tujuan situasional ditetapkan, kriteria kesiapan setiap fungsi dan faktor-faktornya ditetapkan. Kriteria inilah yang akan digunakan sebagai standar atau kriteria untuk mengukur tingkat kesiapan setiap fungsi dan faktor-faktornya.

3. Mengidentifikasi fungsi-fungsi yang perlu dilibatkan untuk mencapai tujuan situasional dan yang masih perlu diteliti tingkat kesiapannya. Untuk mencapai tujuan situasional yang telah ditetapkan maka perlu diidentifikasi fungsi-fungsi mana yang perlu dilibatkan untuk mencapai tujuan situasional dan yang masih perlu diteliti tingkat kesiapannya. Fungsi-fungsi yang dimaksud meliputi antara lain: pengembangan kurikulum, pengembangan tenaga kependidikan dan nonkependidikan, pengembangan siswa, pengembangan iklim akademik sekolah, pengembangan hubungan sekolah-masyarakat, pengembangan fasilitas dan fungsi-fungsi lain.

4. Menentukan tingkat kesiapan setiap fungsi dan faktor-faktornya melalui analisis SWOT (Strength, Weaknes, Opportunity, and Threat). Analisis SWOT dilakukan dengan maksud mengenali tingkat kesiapan setiap fungsi dari keseluruhan fungsi yang diperlukan untuk mencapai tujuan situasional yang telah ditetapkan. Berhubung tingkat kesiapan fungsi ditentukan oleh tingkat kesiapan masing-masing faktor yang terlibat pada setiap fungsi, maka analisis SWOT dilakukan terhadap keseluruhan faktor dalam setiap fungsi, baik faktor yang tergolong internal maupun eksternal. Tingkat kesiapan harus memadai, artinya, minimal memenuhi ukuran kesiapan yang diperlukan untuk mencapai tujuan situasional, yang dinyatakan sebagai: kekuatan, bagi faktor yang tergolong internal; peluang bagi faktor yang tergolong faktor eksternal. Sedang tingkat kesiapan yang kurang memadai, artinya tidak memenuhi ukuran kesiapan, dinyatakan bermakna: kelemahan, bagi faktor yang tergolong faktor internal; dan ancaman, bagi faktor yang tergolong faktor eksternal.

5. Memilih langkah-langkah pemecahan (peniadaan) persoalan, yakni tindakan yang diperlukan untuk mengubah fungsi yang tidak siap menjadi fungsi yang siap. Selama masih ada persoalan, yang sama artinya dengan ada ketidaksiapan fungsi, maka tujuan situasional yang telah ditetapkan tidak akan tercapai. Oleh karena itu, agar tujuan situasional tercapai, perlu dilakukan tindakan-tindakan yang mengubah ketidaksiapan menjadi kesiapan fungsi. Tindakan yang dimaksud lazimnya disebut langkah-langkah pemecahan persoalan, yang hakikatnya merupakan tindakan mengatasi makna kelemahan dan/atau ancaman, agar menjadi kekuatan dan/atau peluang, yakni dengan memanfaatkan adanya satu/lebih faktor yang bermakna kekuatan dan/atau peluang.

6. Berdasarkan langkah-langkah pemecahan persoalan tersebut, 
sekolah bersama-sama dengan semua unsur-unsurnya membuat rencana untuk jangka pendek, menengah, dan panjang, beserta program-programnya untuk merealisasikan rencana tersebut. Sekolah tidak selalu memiliki sumber daya yang cukup untuk melaksanakan manajemen berbasis sekolah idealnya, sehingga perlu dibuat sekala prioritas untuk rencana jangka pendek, menengah, dan panjang.

7. Melaksanakan program-program untuk merealisasikan rencana jangka pendek manajemen berbasis sekolah. Dalam pelaksanaan, semua input yang diperlukan untuk berlangsungnya proses (pelaksanaan) manajemen berbasis sekolah harus siap. Jika input tidak siap/tidak memadai, maka tujuan situasional tidak akan tercapai. Yang perlu diperhatikan dalam pelaksanaan adalah pengelolaan kelembagaan, pengelolaan program, dan pengelolaan proses belajar mengajar.

8. Pemantauan terhadap proses dan evaluasi terhadap hasil manajemen berbasis sekolah perlu dilakukan. Hasil pantauan proses dapat digunakan sebagai umpan balik bagi perbaikan penyelenggaraan dan hasil evaluasi dapat digunakan untuk mengukur tingkat ketercapaian tujuan situasional yang telah dirumuskan. Demikian kegiatan ini dilakukan secara terus-menerus, sehingga proses dan hasil manajemen berbasis sekolah dapat dioptimalkan.

\section{KESIMPULAN}

Manajemen Berbasis Madrasah (MBM) merupakan sebuah konsep alternatif dalam konteks desentralisasi pendidikan yang menempatkan wewenangan pengelolaan madrasah sebagai entitas sistem. MBM merupakan model manajemen yang memberikan wewenang kepada madrasah untuk mengatur dirinya secara leluasa. Dalam konteks ini, warga madrasah mendapat limpahan wewenang untuk melakukan inovasi kurikulum, metode pembelajaran dan penyelenggaraan madrasah.

MBM sebagai model manajemen yang memberikan otoritas pengambilan keputusan dari pemerintah (kementerian Agama) kepada individual sekolah/madrasah. Dengan fleksibilitas/keluwesan dalam pengelolaannya mendorong partisipasi secara langsung warga madrasah dan masyarakat kepada madrasah, dan untuk peningkatan mutu pendidikan dalam kerangka pendidikan nasional.

1. Manajemen tenaga pendidik, peserta didik dan disain kurikulum di MAN 4 Jakarta sudah mengarah kepada MBS, hal ini dibuktikan dengan adanya perancanaan yang matang dan terorganisir sesuai dengan visi dan misi madrasah

2. Dalam manajemen tenaga pendidik sering terjadi miskomunikasi antara pemerintah pusat (kanwil kemenang) dengan pihak madrasah dalam penempatan dan perekrutan guru.

3. Dukungan dari pemerintah pusat dalam rangka otonomi sekolah khususnya yang berkaitan dengan manajemen peserta didik dapat 
dikatakan baik dengan diberikannya berbagai bantuan baik finansial maupun non finansial. Namun hal tersebut berimplikasi pada intervensi kebijakan dan pengelolaan penerimaan peserta didik khususnya dan madrasah pada umumnya.

\section{REKOMENDASI}

Ukuran prestasi harus ditetapkan multidimensional, jadi bukan hanya pada dimensi prestasi akademik. Dengan taruhan seperti itu, madrasah-madrasah yang hanya menerapkan MBM sebagai model akan memiliki peluang yang kecil untuk berhasil.

Untuk itu penulis memberikan beberapa saran yang mungkin bisa dijadikan masukan dalam rangka menuju sekolah yang mandiri dan bermutu, di antaranya:

1. Pemerintah dalam hal ini Kementerian Agama harus lebih yakin sepenuhnya terhadap satuan pendidikan/madrasah dalam hal ini
MAN 4 Jakarta untuk dapat lebih leluasa mengelola dan menentukan arah kebijakannya sendiri.

2. Kepala MAN 4 Jakarta harus lebih pandai dan jeli dalam melihat, merancang dan mengkoordinir unit yang dipimpin sehingga bisa melangkah lebih maju secara transparan dan akuntabel.

3. Peningkatan sinergi kerja sama antar elemen dalam masyarakat sekolah dalam mengapai tujuan bersama. MAN 4 agar lebih giat membuka jalur komunikasi dengan Tokoh masyarakat, alumni dan dunia usaha/dunia industri (DU/DI).

4. Paradigma berpikir penerapan MBM hendaknya tetap berorientasi kepada upaya peningkatan mutu pembelajaran yang akan nantinya akan berimplikasi pada mutu peserta didik lulusan madrasah di masa yang datang.

\section{DAFTAR PUSTAKA}

Anderson, W. 2006. School leadership: Handbook for excellence in student learning. London: Sage.

Amdowirio, Soebagio. 2000. Manajemen Pendidikan Indonesia. Jakarta: Ardadizjaya. Arikunto, Suharsimi. 2008. Manajemen Pendidikan. Yogyakarta: Aditya Media F. Ilmu Pendidikan UNY

Bandur, A. School-ba sed manage me $n t$ developments and partnership. International Journal of Educational Development, ( $\left.\begin{array}{llll}2 & 0 & 1 & 2\end{array}\right)$

Bjork, C. Local responses to decentralization policy in Indonesia. (Comparative Education Review, No. 47;2003).)

B. JR. William Whitaaker, Human Resources And Personal Management (New York: McCraw-Hill Publications, 2003)

B. Suryosubroto, Manajemen Penddidikan Di Sekolah (Jakarta: Rineka Cipta, 2004) 
Brian J. Cadwel Dan Jim M. Spink, Student Outcomensand The Reform Of Education Beyond The Self-Managing School (Hongkong: Graphicraft, 1998)

Bafadal, Ibrahim, Manajemen Peningkatan Mutu Sekolah Dasar (Jakarta: Bumi Aksara, 2006)

Caldwell, B. J. Reconceptualizing the selfmanaging school. Educational Management Administration \& Leadership, (2008).

Dharma, Manajemen Berbasis Sekolah : Belajar Dari Pengalaman Orang Lain, (Http://Artikel.Us/Adharma2.Html, Diakses Tanggal 23 April 2017).

Eko Widodo,Suparno Peningkatan Kemampuan Manajerial Kepala Sekolah Dalam

Perspektif Pembaharuan Pendidikaan Islam, Dalam " Mereka Bicara Pendidikan Islam Sebuah Bunga Rampai" (Jakarta: Raja Grafindo Persada, 2009)

Hadi Miarso,Yusuf Menyemai Benih Tekhnologi Pendidikan (Jakarta: Kencana, 2004

Jenni, R.W. Application Of The School Based Management (SBM) Process Development

Model. School Effektiveness And Scholl Improvement, (ISSN 0924, Volume, Nomor 2,1991)

Mulyasa, Enco Manajemen Berbasis Sekolah Konsep, Strategi Dan Implementasi Bandung:Remaja Rosdakarya, 2009)

Slamet PH. Manajemen Berbasis Sekolah. (Yogyakarta: Universitas Negeri Yogyakarta, 2004).

Soecipto, Profesi Keguruan (Bandung: Rineka Cipta, 1999)

Sallis,Edwar, Total Quality Management In Education, Ahmad Ali Riyadi (Terj.) (Jogjakarta: Ircisod, 2008)

Susan Albers Moharman, School-Based Manajeman: Organizing for High Performance (San Fransisco: Jossey Bass, 1994),

Tilaar, Paradigma Pendidikan Nasional (Jakarta: Rineka Cipta, 2000)

Husaini, Usman,Manajemen ; Teori, Praktik \& Risest Pendidikan (Jakarta: Bumi Aksara, 2011)

Mustiningsih, Masalah Implementasi Manajemen Berbasis Sekolah Di Sekolah Dasar, Jurnal Manajemen Pendidikan, Volume 24, Nomor 6, September 2015

Nurdin,Diding Manajemen Pendidikan Dalam IImu Dan Aplikasi Pendidikan (Bandung: Imprial Bakti Utama)

Priscilla Wohlstetter Dan Susan Albert Mohrman, Assesment Of School Based Management Studies of Education Reformn (US: Departement Of Education Office Of Education Research And Improvement, 1996)K.M. Lindquist Dan J.J. Mauriel, School Based Management To Failure? Education And Urban Society, (Online), Volume 21, Nomor 4,1989. Pp. 403-416.

Undang-Undang Nomor 20 Tahun 2003 tentang Sistem Pendidikan Nasional (Jakarta: Kementerian Pendidikan Nasional)

Veithzal Rivai, Education Management, Analisis Teori dan Praktik, (Jakarta: Rajawali Pers, 2009) 